\title{
Storage of 'Espada' mango fruits in modified atmosphere and cooling: effects on conservation
}

\author{
Juliana Altafin GaLLI ${ }^{1 *}$, Maria Beatriz Bernardes SoARes ${ }^{1}$, Antonio Lucio Melo MARTINS ${ }^{1}$, Julio Cesar Galli ${ }^{2}$
}

${ }^{1}$ Apta Centro Norte, Caixa Post. 24, CEP: $15830-000$, Pindorama-SP, Brazil, julianagalli@apta.sp.gov.br, beatriz@apta.sp.gov.br, Imartins@apta.sp.gov.br

2 Dep. of Plant health FCAV / UNESP, Via Access Prof. Paulo Donato Castellane s/n, CEP: 14884-900, Jaboticabal-SP, Brazil, jcgalli@fcav.unesp.br

${ }^{*}$ Correspondence and reprints

Received 25 May 2012 Accepted 16 August 2012

Fruits, 2013, vol. 68, p. 291-302 (C) 2013 Cirad/EDP Sciences All rights reserved DOI: $10.1051 /$ fruits/2013076 www.fruits-journal.org

RESUMEN EsPAÑOL, p. 302

\section{Storage of 'Espada' mango fruits in modified atmosphere and cooling: effects on conservation.}

Abstract - Introduction. Brazil is a major producer of mangoes, but the export volume is still small because of the short shelf life of this fruit. The objectives of our work were to evaluate the effect of modifying the storage atmosphere using plastic film and temperature, according to different periods of storage, on the characteristics of Espada mango grown organically. Material and methods. Seven treatments were applied to the fruits after their harvest: fruits stored at room temperature; at $12{ }^{\circ} \mathrm{C} / 80-90 \%$ relative humidity $(\mathrm{RH})$; washed and stored at room temperature; washed and stored at $12{ }^{\circ} \mathrm{C} / 80-90 \% \mathrm{RH}$; washed, packed in PVC and stored at room temperature; washed, packaged in PVC and stored at $12{ }^{\circ} \mathrm{C} / 80-90 \% \mathrm{RH}$; and fruits harvested on the same day of evaluations, at (5, 9, 13, 16 and 21) days of storage. Results and discussion. Storage at $12{ }^{\circ} \mathrm{C}$ and $80-90 \% \mathrm{RH}$ was more efficient in delaying fruit ripening, with minor evolution of peel and pulp color and soluble solids contents; this treatment also delayed the development of anthracnose. Fruits packed in PVC and stored at room temperature kept the peel and pulp color for 13 days, compared with 9 days for non-packaged fruits. The ideal time to harvest the Espada variety occurs at 165 days after the onset of flowering, with an index of " 3 " for skin color (equal amounts of green and yellow) and pulp color (yellow pulp), and soluble solids of $8.5^{\circ}$ Brix. The low severity of anthracnose found at different evaluation times indicates the probable tolerance of the Espada variety to the pathogen.

Brazil / Mangifera indica / fruits / postharvest ripening / controlled atmosphere storage / keeping quality

\section{Stockage de mangues 'Espada' sous atmosphère modifiée et réfrigérée : effets sur la conservation des fruits.}

Résumé-Introduction. Le Brésil est un important producteur de mangues, mais le volume des exportations est encore faible en raison de la courte durée de conservation de ces fruits. L'objectif de notre travail a été d'évaluer, en fonction de différentes périodes de conservation, l'effet de la modification de l'atmosphère de stockage par utilisation d'un film plastique, ainsi que l'effet de la température de stockage, sur les caractéristiques de mangues Espada cultivées biologiquement. Matériel et méthodes. Sept traitements ont été appliqués aux fruits après leur récolte : fruits conservés à température ambiante ; à $12{ }^{\circ} \mathrm{C} / 80-90 \%$ d'humidité relative (HR) ; lavés et stockés à température ambiante ; lavés et stockés à $12{ }^{\circ} \mathrm{C} / 80-90 \% \mathrm{HR}$; lavés, emballés sous PVC et conservés à température ambiante; lavés, emballés et stockés sous PVC à $12{ }^{\circ} \mathrm{C} / 80-90 \%$ HR; fruits récoltés à la même date que les évaluations effectuées après $(5,9,13,16$ et 21) jours de stockage pour les six autres traitements. Résultats et discussion. Le stockage à $12{ }^{\circ} \mathrm{C} / 80-90 \%$ HR a été le plus efficace pour retarder le mûrissement des fruits, avec une évolution mineure des couleurs de peau et de pulpe et des teneurs en solides solubles ; ce traitement a aussi retardé le développement de l'anthracnose. Les fruits conservés sous PVC et placés à la température ambiante ont conservé leur couleur de peau et de pulpe pendant 13 jours, comparativement à 9 jours de conservation pour les fruits non emballés. Le meilleur moment pour récolter la variété Espada serait 165 jours après le début de la floraison, avec un indice de couleur de 3 pour la peau (quantités égales de vert et de jaune) et pour la pulpe (pulpe jaune), et une teneur en solides solubles de $8,5^{\circ}$ Brix. La faible sévérité d'anthracnose trouvée aux différentes dates d'évaluation indiquerait une probable tolérance de la variété Espada à l'agent pathogène.

Brésil / Mangifera indica / fruits / maturation après récolte / stockage en atmosphère contrôlée / aptitude à la conservation 


\section{Introduction}

Brazil is a major producer of mangoes, but the export volume is still small, mainly due to the short shelf life of the product, which should be handled with specific care during shipping. Mangoes harvested at a mature but unripe stage of development ('maturegreen') can be stored in the unripe state as long as the initiation of ethylene production, and hence ripening, is avoided. The initiation of ripening can be avoided by prompt cooling and storage at a low temperature at which ripening does not occur or, more effectively, by changing the composition of the storage atmosphere so that the oxygen $\left(\mathrm{O}_{2}\right)$ level is reduced and carbon dioxide $\left(\mathrm{CO}_{2}\right)$ level is raised [1].

Through the creation and maintenance of an optimal micro-atmosphere, packaging of fruit in plastic film reduces the rates of respiration, perspiration and microbial growth and slows down several other metabolic reactions occurring in the product $[2,3]$. However, a combination of packaging and temperature may cause an inadequate oxygen supply and / or insufficient output of carbon dioxide through the packaging, creating an atmosphere not appropriate for the fruit, which may result in undesirable changes in color and texture and the development of non-characteristic flavor and odor [4]. The literature cites the use of plastic films (polyethylene, polypropylene, various copolymers of high permeability) to pack individual mangoes of different cultivars, such as Tommy Atkins [4], Palmer [5] and Keitt [3]. Polyvinyl chloride (PVC) film has low cost and high gas permeability and was used by Jerônimo and Kanesiro [6] to cover trays containing mango cv. Palmer.

The optimum ripening temperature range for high-quality mango varies from $19{ }^{\circ} \mathrm{C}$ to $24^{\circ} \mathrm{C}[7]$. However, to extend the shelf life period, it is recommended to use temperatures around $13{ }^{\circ} \mathrm{C}$ and a relative humidity varying from $85 \%$ to $90 \%$; these conditions are described as ideal for a large number of cultivars, especially when they are harvested at the pre-climacteric stage $[8,9]$.

Mango fruit quality is compromised when harvest occurs before the fruit are fully mature, since they are unable to achieve the full complement of flavor and aroma during the postharvest handling period compared with fruit harvested at a fully mature or ripening-initiated stage of development [10].

The objectives of our study were to evaluate the effects of modifying the storage atmosphere by plastic film and the temperature at different periods of storage on the physico-chemical characteristics and quality of the 'Espada' mango variety grown organically.

\section{Materials and methods}

The 'Espada' mangoes used in our experiment were from the experimental field of Apta Centro Norte, Pindorama-SP, Brazil, lat. $21^{\circ} 13^{\prime} \mathrm{S}$ and long. $48^{\circ} 55^{\prime} \mathrm{W}$, with average annual temperature of $22.8^{\circ} \mathrm{C}$, average annual rainfall of $1390.3 \mathrm{~mm}$ and annual relative humidity of $71.6 \%$. The field was installed in 2007 as an organic production system.

Fruits from five plants were manually harvested on October 26, 2011, 125 days after the onset of flowering. Fruits with greencolored skin of approximately similar size and maturity stage were selected on the basis of absence of defects and diseases.

Fruits were transported to the laboratory immediately after harvest. They were randomly assigned to seven treatments varying the storage temperature and the packaging (table I).

The evaluations conducted after $(5,9,13$, 16 and 21) days of storage were made with five replications (fruit) per treatment. Fruits assessed on the harvest day (125 days after the onset of flowering) served as reference control.

Skin color was evaluated visually with the rating scale described by Hiluey et al. [11]: $1=$ green fruit, $2=$ more green than yellow, 3 = equal amounts of green and yellow, $4=$ more yellow than green, and $5=$ completely yellow fruits. Pulp color was assessed visually from a longitudinal cut section of the fruit using a subjective scale scoring from 1 to 5 , where 1 = light cream pulp, $2=$ cream pulp, $3=$ light yellow pulp, 


\begin{tabular}{|c|c|}
\hline Treatments & Description \\
\hline T 1 & Fruits stored at room temperature \\
\hline T 2 & Fruits stored at $12{ }^{\circ} \mathrm{C}$ with $80-90 \%$ of relative humidity \\
\hline T3 & $\begin{array}{l}\text { Fruits washed in chlorinated water by immersing them in } 0.1 \mathrm{~mL} \cdot \mathrm{L}^{-1} \text { chlorine for } 15 \mathrm{~min} \text {, then dried with a paper } \\
\text { towel and stored at room temperature }\end{array}$ \\
\hline T 4 & Fruits washed in chlorinated water, then stored at $12^{\circ} \mathrm{C}$ and $80-90 \%$ of relative humidity \\
\hline T 5 & $\begin{array}{l}\text { Fruits washed in chlorinated water, packed manually with a layer of plastic film (PVC), then stored at room } \\
\text { temperature }\end{array}$ \\
\hline T 6 & Fruits washed in chlorinated water, packaged in PVC, then stored at $12{ }^{\circ} \mathrm{C}$ and $80-90 \%$ of relative humidity \\
\hline T 7 & $\begin{array}{l}\text { Fruits harvested on the same day of evaluations (fresh fruits) at }(130,134,138,141 \text { and } 146) \text { days after the onset of } \\
\text { flowering }\end{array}$ \\
\hline
\end{tabular}

$4=$ yellow-orange pulp and $5=$ orange intense pulp [11]. Pulp yield was obtained from individual fruits, which were peeled close to the pulp with a stainless steel knife. The weight of the entire fruit, and of the peel and seed, were recorded with an analytical balance to three decimal places. The pulp yield was computed as the difference from the whole fruit, reported as a percentage. Soluble solids were determined by direct readings with a handheld refractometer (Atago, model N1, 32-10 Honcho, Itabashiku, Tokyo 173-0001, Japan), using three drops of homogenized pulp, obtained by peeling the fruit and processing in a domestic centrifuge. The results were expressed in ${ }^{\circ}$ Brix. Anthracnose severity was assessed by the adaption of the graphic scale described by Sales Junior et al. [12], assigning notes to the symptoms: $1=$ no anthracnose spots on the fruits, $2=$ less than $5.0 \%$ of the fruit area affected with anthracnose, $3=5.0 \%$ to $10.0 \%$ of the fruit area affected with anthracnose, $4=10.1 \%$ to $30.0 \%$ of the fruit area affected with anthracnose, and $5=$ more than $30.1 \%$ of the fruit area affected with anthracnose.

The experimental design used was randomized blocks in factorial outline $5 \times 7+1$ [storage at $(5,9,13,16$ and 21) days $x$ 7 treatments (storage conditions) + control (fruit evaluated at 125 days after the onset of flowering)], a total of 36 treatments and five repetitions. The data were subjected to variance analysis by the $F$ test and means were separated with Tukey's test at 5\% probability.

Evaluations of fruits collected on the day of evaluations (treatment 7 , fresh fruit) continued until December 16, at (151, 159, 162, 167, 172 and 176) days after the onset of flowering to follow on tree fruit ripening. Regression analysis was performed, testing the linear, quadratic, cubic and regression deviation, and the equation parameters were selected using the $F$ test.

\section{Results and discussion}

The results regarding the parameters skin color, pulp color, pulp yield, soluble solids and severity of anthracnose assessed by analysis of variance showed that only the parameter percentage of pulp yield was not significantly different from control (table IIa). The data for the other parameters differed significantly from the value of control. For anthracnose severity, no significant interaction appeared between days of storage and treatments. Greater severity of anthracnose was observed at 21 days of storage, being significantly different from the 13th day (table IIb). With respect to treatments, the highest severity was observed in treatments 1 and 5, although they did not differ significantly from the treatments 3 and 6 (table IIC).

Despite the fact that harvest was carried out at 125 days after flowering initiation 
Table II.

Analysis of variance for the mean of parameters skin color, pulp color, pulp yield (\%), soluble solids and severity of anthracnose of mangoes 'Espada' submitted to different storage treatments for studying the effects of cooling, packaging and storage periods on fruits after harvest (South Brazil).

a) ANOVA results

\begin{tabular}{|c|c|c|c|c|c|}
\hline ANOVA parameters & Skin color & Pulp color & $\begin{array}{l}\text { Pulp yield } \\
\text { (\%) }\end{array}$ & $\begin{array}{c}\text { Soluble solids } \\
\text { ( }{ }^{\circ} \text { Brix) }\end{array}$ & Severity of anthracnose \\
\hline F (Control $\times$ Factorial) & $7.27^{\star \star}$ & 25.79 ** & $0.22 \mathrm{~ns}$ & $17.79^{\star \star}$ & 5.60 * \\
\hline F (Period) & $27.87^{\star *}$ & 146.62 ** & $26.03^{* *}$ & $24.63^{* *}$ & $5.55^{* *}$ \\
\hline $\mathrm{F}$ (Treatments) & $19.41^{\star *}$ & $88.87^{\star \star}$ & $23.00^{* *}$ & $34.06^{* *}$ & $4.61^{* *}$ \\
\hline F (Period x Treatments) & $2.38^{* \star}$ & $14.23^{\star \star}$ & $4.23^{\star \star}$ & $2.08^{* \star}$ & $1.57 \mathrm{~ns}$ \\
\hline Coefficient of variation (\%) & 25.17 & 22.45 & 3.77 & 7.80 & 39.09 \\
\hline
\end{tabular}

b) Factor studied: storage period

\begin{tabular}{|c|c|c|c|c|c|}
\hline $\begin{array}{l}\text { Storage periods } \\
\text { (days) }\end{array}$ & Skin color & Pulp color & $\begin{array}{l}\text { Pulp yield } \\
\text { (\%) }\end{array}$ & $\begin{array}{l}\text { Soluble solids } \\
\text { ('Brix) }\end{array}$ & Severity of anthracnose \\
\hline 5 & $1.63 \mathrm{~b}$ & $1.03 \mathrm{c}$ & $74.16 \mathrm{a}$ & $6.60 \mathrm{c}$ & $1.43 \mathrm{~b}$ \\
\hline 9 & $1.91 \mathrm{~b}$ & $1.29 \mathrm{c}$ & $74.29 \mathrm{a}$ & $7.31 \mathrm{~b}$ & $1.57 \mathrm{~b}$ \\
\hline 13 & $2.69 \mathrm{a}$ & $2.17 \mathrm{~b}$ & $73.51 \mathrm{ab}$ & $7.58 \mathrm{ab}$ & $1.80 \mathrm{ab}$ \\
\hline 16 & $2.46 \mathrm{a}$ & $2.37 \mathrm{~b}$ & $72.27 b$ & $7.77 \mathrm{a}$ & $1.63 \mathrm{~b}$ \\
\hline 21 & $2.83 \mathrm{a}$ & $3.34 \mathrm{a}$ & $68.92 \mathrm{c}$ & $7.74 \mathrm{a}$ & $2.11 \mathrm{a}$ \\
\hline Control & 1.60 & 1.00 & 73.22 & 6.3 & 1.0 \\
\hline Significant minimum difference & 0.3800 & 0.2985 & 1.8122 & 0.3802 & 0.4365 \\
\hline \multicolumn{6}{|c|}{ c) Factor studied: storage treatment } \\
\hline $\begin{array}{l}\text { Storage conditions } \\
\text { (treatments) }\end{array}$ & Skin color & Pulp color & $\begin{array}{l}\text { Pulp yield } \\
\text { (\%) }\end{array}$ & $\begin{array}{l}\text { Soluble solids } \\
\text { ('Brix) }\end{array}$ & Severity of anthracnose \\
\hline Room $\mathrm{T}^{\circ}$ & $2.80 a b$ & $2.96 \mathrm{a}$ & $70.33 \mathrm{de}$ & $8.14 \mathrm{a}$ & $2.08 \mathrm{a}$ \\
\hline $12{ }^{\circ} \mathrm{C} / 80-90 \% \mathrm{RH}$ & $1.84 \mathrm{de}$ & $1.24 \mathrm{~d}$ & $73.48 \mathrm{bc}$ & $7.13 \mathrm{~b}$ & $1.48 \mathrm{~b}$ \\
\hline Washed + room $\mathrm{T}^{\circ}$ & $3.04 \mathrm{a}$ & $3.24 \mathrm{a}$ & 68.19 e & $8.54 \mathrm{a}$ & $1.80 \mathrm{ab}$ \\
\hline Washed $+12^{\circ} \mathrm{C} / 80-90 \% \mathrm{RH}$ & $1.60 \mathrm{e}$ & $1.04 \mathrm{~d}$ & $73.55 \mathrm{bc}$ & $7.22 \mathrm{~b}$ & $1.48 \mathrm{~b}$ \\
\hline $\begin{array}{l}\text { Washed + packed with PVC } \\
+ \text { room } \mathrm{T}^{\circ}\end{array}$ & $2.20 \mathrm{~cd}$ & $2.44 \mathrm{~b}$ & $71.65 \mathrm{~cd}$ & $6.88 \mathrm{~b}$ & $2.04 \mathrm{a}$ \\
\hline $\begin{array}{l}\text { Washed + packed with PVC } \\
+12^{\circ} \mathrm{C} / 80-90 \% \mathrm{RH}\end{array}$ & $2.20 \mathrm{~cd}$ & $1.72 \mathrm{c}$ & $74.67 \mathrm{ab}$ & $7.12 b$ & $1.72 \mathrm{ab}$ \\
\hline Fresh fruits & $2.44 \mathrm{bc}$ & $1.64 \mathrm{c}$ & $76.54 \mathrm{a}$ & $6.76 \mathrm{~b}$ & $1.36 \mathrm{~b}$ \\
\hline Significant minimum difference & 0.4863 & 0.3820 & 2.3189 & 0.4865 & 0.5586 \\
\hline
\end{tabular}

Means followed by the same letter in a column do not differ by Tukey's test at $5 \%$ probability; ${ }^{\star *}$ : Significant at $1 \%$ probability;

*: Significant at $5 \%$ probability; ns: not significant.

- Skin color: 1 = green fruit, 2 = more green than yellow, 3 = equal amounts of green and yellow, 4 = more yellow than green, and $5=$ completely yellow fruits.

- Pulp color: 1 = light cream pulp, 2 = cream pulp, 3 = light yellow pulp, 4 = yellow-orange pulp, and 5 = orange intense pulp.

- Anthracnose severity: 1 = no anthracnose spots on the fruits, 2 = less than $5.0 \%, 3=5.0 \%$ to $10.0 \%, 4=10.1 \%$ to $30.0 \%$, and $5=$ more than $30.1 \%$ of the fruit area affected, respectively. 
when the skin color was at an average value of $1.60(1=$ green fruit and $2=$ more green than yellow), the soluble solids $\left(6.3^{\circ} \mathrm{Brix}\right.$, on average) of the control fruits were low (table IIb). These observations are indicative that these parameters are not sufficient for determining the appropriate harvest stage. Mango fruits reach maturity 100-150 days after flowering [13], depending on the cultivar and climate. According to Filgueiras [14], age of the fruit is a very safe method to assess the maturity of mangoes, but its use is more reliable in regions where there is little rain, with little change in temperature during the fruiting period. This author recommends the minimum maturation for some mango varieties. For Tommy Atkins at harvest, it was established that, for optimum quality development, pulp color should be at 1 (cream color, varying from light cream to dark cream), skin color at 2 (olive-green color which turns bright light green), firmness equal to $129.45 \mathrm{~N}$, and soluble solids at $7.3^{\circ}$ Brix. For Haden, Kent and Keitt, firmness should be at $119.64 \mathrm{~N}, 121.60 \mathrm{~N}$ and $107.87 \mathrm{~N}$, respectively. Soluble solids should be $7.3^{\circ} \mathrm{Brix}, 7.4^{\circ} \mathrm{Brix}$ and $6.6^{\circ} \mathrm{Brix}$ for Haden, Kent and Keitt, respectively. There is a need for more information on other varieties such as "Espada" as affected by production localities to establish the ideal harvest point so that the fruits are able to mature with desirable visual and organoleptic qualities.

The anthracnose severity was 2.11 at 21 days of storage (table IIb) with less than $5 \%$ of the fruit area affected by anthracnose. This value indicates that the disease index was low considering that fruits were produced in an organic system, without fungicide application during development. All mango fruits evaluated in this experiment were harvested without the presence of symptoms of the disease.

According to Prusky et al. [15], in the case of postharvest anthracnose, developing fruits are infected in the field, but the infections remain quiescent until the onset of ripening, which occurs after harvest. Once the climacteric period of the fruit starts, lesions begin to develop but there is no fruit-to-fruit infection. Among treatments, fruits stored at $12{ }^{\circ} \mathrm{C}$ (T2) and fruits washed and stored at
$12{ }^{\circ} \mathrm{C}$ (T4) showed the lowest ratings of anthracnose severity (table IIc), indicating that storage at low temperatures retards the development of the pathogen.

Although not statistically different, anthracnose severity was lower in fruits immersed in chlorinated water and stored at room temperature (T3, severity 1.80) than in fruits stored at room temperature without the washing (T1, 2.08 severity ) (table IIc). The low anthracnose severity observed in fresh fruits (T7) is an indication that either the symptoms have not yet manifested visually or the variety is resistant.

In relation to skin color, the unfolding of the interaction among treatments and storage days revealed that for fruits stored at room temperature (T1) and fruits packed with PVC (T5) and stored at room temperature, there was a significant change in color evolution from the 13th day of storage (table III). There was no significant difference in skin color during storage periods for fruits stored at $12{ }^{\circ} \mathrm{C}$ (T2) and fruits washed before storing at $12{ }^{\circ} \mathrm{C}(\mathrm{T} 4)$; no sign of ripening was visible as the skin color evolved from 1 to 2.4 (unripe and greener than yellow, respectively). For fruits washed before storing at room temperature (T3), fruits packed with PVC before storing at $12{ }^{\circ} \mathrm{C}$ (T6) and control fruits (T7), the skin color differed significantly from the 9th storage day. Among the treatments, no significant difference was observed after the 5 th day of storage. On the 9th and 13th days, the highest values were observed for treatments T3, T1, T7 and T6, which did not differ statistically from each other. On the 16th day, treatments T1 and T3 showed a higher value for skin color, differing from treatments T2 and T4; after 21 days of storage, the highest color values were obtained for treatments T1, T3 and T5.

Maintenance of skin color in fruits stored at $12{ }^{\circ} \mathrm{C}$ (T2) and fruits washed and stored at $12{ }^{\circ} \mathrm{C}(\mathrm{T} 4)$ over the 21 days of storage (table III) indicated that storage at $12{ }^{\circ} \mathrm{C}$ slowed down the ripening process. The modification of the atmosphere by the use of PVC slowed the development of skin color, as compared with other treatments with storage at room temperature, but the cold storage was more effective. 


\section{Table III.}

Averages of the unfolding interaction between storage periods and storage conditions for the parameter skin color of 'Espada' mangoes submitted to different treatments applied to fruits after harvest (South Brazil) (skin color: 1 = green fruit, 2 = more green than yellow, 3 = equal amounts of green and yellow, $4=$ more yellow than green, and $5=$ completely yellow fruits).

\begin{tabular}{|c|c|c|c|c|c|c|c|c|c|c|c|c|c|c|c|}
\hline \multirow{3}{*}{ 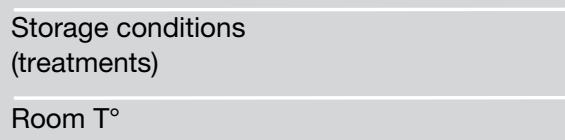 } & \multicolumn{15}{|c|}{ Storage periods (days) } \\
\hline & \multicolumn{3}{|c|}{5} & \multicolumn{3}{|c|}{9} & \multicolumn{3}{|c|}{13} & \multicolumn{3}{|c|}{16} & \multicolumn{3}{|c|}{21} \\
\hline & 1.8 & C & a & 2.2 & $\mathrm{BC}$ & $a b$ & 3.2 & $\mathrm{AB}$ & $a b$ & 3.0 & $A B$ & a & 3.8 & A & a \\
\hline $12{ }^{\circ} \mathrm{C} / 80-90 \% \mathrm{RH}$ & 2.0 & $A$ & a & 1.6 & $A$ & $\mathrm{bc}$ & 1.6 & A & $d$ & 1.6 & A & $\mathrm{b}$ & 2.4 & $A$ & bc \\
\hline Washed + room $\mathrm{T}^{\circ}$ & 1.8 & B & a & 2.8 & $A B$ & a & 3.6 & A & a & 3.2 & $A$ & $\mathrm{a}$ & 3.8 & $A$ & $\mathrm{a}$ \\
\hline Washed $+12^{\circ} \mathrm{C} / 80-90 \% \mathrm{RH}$ & 1.4 & $A$ & a & 1.0 & $A$ & c & 2.0 & A & $\mathrm{cd}$ & 1.6 & $A$ & $\mathrm{~b}$ & 2.0 & $A$ & c \\
\hline $\begin{array}{l}\text { Washed + packed with PVC } \\
+ \text { room } T^{\circ}\end{array}$ & 1.2 & $\mathrm{C}$ & a & 1.6 & $\mathrm{BC}$ & bc & 2.4 & $A B$ & bcd & 2.6 & $A B$ & $a b$ & 3.2 & A & $a b$ \\
\hline $\begin{array}{l}\text { Washed + packed with PVC } \\
+12{ }^{\circ} \mathrm{C} / 80-90 \% \mathrm{RH}\end{array}$ & 1.4 & $\mathrm{~B}$ & a & 2.0 & $A B$ & $a b c$ & 2.8 & A & $a b c$ & 2.6 & A & $a b$ & 2.2 & $A B$ & bc \\
\hline Fresh fruits & 1.8 & $\mathrm{~B}$ & a & 2.2 & $A B$ & $a b$ & 3.2 & A & $a b$ & 2.6 & $A B$ & $a b$ & 2.4 & $A B$ & bc \\
\hline $\begin{array}{l}\text { Significant minimum difference } \\
\text { (storage periods) }\end{array}$ & & & & & & & & 1.005 & & & & & & & \\
\hline Significant minimum difference (treatments) & & & & & & & & 1.087 & & & & & & & \\
\hline
\end{tabular}

Pesis et al. related that packing the mango fruit cultivars Tommy Atkins and Keitt in microperforated polyethylene (PE) or in Xtend ${ }^{\circledR}$ films (XF) reduced peel color development by almost $50 \%$ after 21 days at $12{ }^{\circ} \mathrm{C}$ plus 5 days at $20^{\circ} \mathrm{C}[16]$. The least color development was found in fruit packed in PE. González-Aguilar et al. evaluated the quality of Keitt mangoes during storage in modified atmosphere packaging (MAP) with polyethylene (LDPE) films and they observed delay in the loss of color, weight and firmness [17] Fruit maintained good appearance with a significant delay in ripening. Both results agree with Alves et al., who reported that packaging in modified atmosphere delayed ripening of Tommy Atkins mangoes stored under refrigeration [18].

For pulp color, fruits stored at room temperature (T1) and fruits washed then packed with PVC and stored at room temperature (T5) showed a differentiation from 13 days of storage, with the highest value observed on the 21st day (table IV). For fruits stored at $12{ }^{\circ} \mathrm{C}$ (T2), a significant difference was observed only after 21 days of storage. For fruits washed then stored at room temperature (T3), pulp color differed significantly from the 9th day, reaching the highest value at 21 days. Fruits washed then stored at $12{ }^{\circ} \mathrm{C}$ (T4) showed no significant change in pulp color (which remained light cream, characteristic of unripe fruit) throughout the period of storage. The refrigeration temperature recommended for mangoes is $12{ }^{\circ} \mathrm{C}$ [18], which means that the fruits were not subjected to abusive temperatures, causing impairment of ripening due to chilling injury. Tommy Atkins fruit have been successfully stored for up to 21 days at $12{ }^{\circ} \mathrm{C}$, with favorable ripening qualities and minimal chilling injury symptoms [16, 19].

In fruits washed then packaged in PVC and stored at $12{ }^{\circ} \mathrm{C}$ (T6), pulp color differed significantly from the 16th day, and fruits of control (T7) had similar color from the 13th day, although reaching low values $(2=$ cream pulp), indicating that fruits did not reach ripening at 146 days after the onset of flowering. With regard to treatments, there was no significant difference on the 5 th day of storage. After the 9th day, only fruits washed and stored at room temperature (T3) differed from the others, with higher pulp color values. By the 13th day, the highest values were observed for treatments $\mathrm{T} 1$ and 


\begin{tabular}{|c|c|c|c|c|c|c|c|c|c|c|c|c|c|c|c|}
\hline \multirow{3}{*}{ 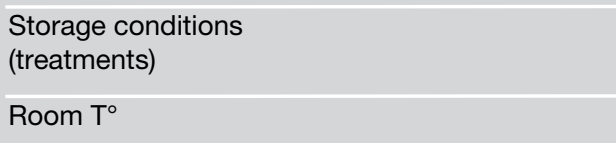 } & \multicolumn{15}{|c|}{ Storage periods (days) } \\
\hline & \multicolumn{3}{|c|}{5} & \multicolumn{3}{|c|}{9} & \multicolumn{3}{|c|}{13} & \multicolumn{3}{|c|}{16} & \multicolumn{3}{|c|}{21} \\
\hline & 1.2 & C & a & 1.2 & C & $b$ & 3.8 & B & a & 3.8 & $\mathrm{~B}$ & a & 4.8 & A & a \\
\hline $12{ }^{\circ} \mathrm{C} / 80-90 \% \mathrm{RH}$ & 1.0 & B & a & 1.0 & B & $b$ & 1.2 & B & c & 1.0 & $\mathrm{~B}$ & $d$ & 2.0 & $A$ & c \\
\hline Washed + room $\mathrm{T}^{\circ}$ & 1.0 & $\mathrm{D}$ & a & 2.4 & C & a & 4.2 & B & a & 3.6 & $\mathrm{~B}$ & $a$ & 5.0 & A & a \\
\hline Washed $+12^{\circ} \mathrm{C} / 80-90 \% \mathrm{RH}$ & 1.0 & A & a & 1.0 & A & b & 1.0 & A & c & 1.0 & A & $d$ & 1.2 & A & c \\
\hline $\begin{array}{l}\text { Washed + packed with PVC } \\
+ \text { room } \mathrm{T}^{\circ}\end{array}$ & 1.0 & $\mathrm{D}$ & a & 1.0 & $D$ & $b$ & 2.2 & $C$ & $b$ & 3.0 & B & $a b$ & 5.0 & A & a \\
\hline $\begin{array}{l}\text { Washed + packed with PVC } \\
+12{ }^{\circ} \mathrm{C} / 80-90 \% \mathrm{RH}\end{array}$ & 1.0 & C & a & 1.0 & C & $b$ & 1.0 & C & c & 2.0 & $\mathrm{~B}$ & $\mathrm{C}$ & 3.4 & A & $b$ \\
\hline Fresh fruits & 1.0 & C & a & 1.4 & $\mathrm{BC}$ & $b$ & 1.6 & $A B$ & $\mathrm{bc}$ & 2.2 & A & bc & 2.0 & $A B$ & c \\
\hline Significant minimum difference (storage periods) & \multicolumn{15}{|c|}{0.7899} \\
\hline Significant minimum difference (treatments) & \multicolumn{15}{|c|}{0.8542} \\
\hline
\end{tabular}

$\mathrm{T} 3$, and, at the 16th and 21st days, for T1, $\mathrm{T} 3$ and $\mathrm{T} 5$, showing characteristics of ripe fruit at 21 days (yellow-orange pulp and orange intense pulp).

There was no significant change in the pulp color in fruit stored at $12{ }^{\circ} \mathrm{C}$ (table IV). Only the fruits stored at room temperature reached the coloration of ripe fruits (score scale 4 and 5) at the 21st day. The fruits packed in PVC and kept at room temperature (T5) began to show signs of maturation from the 16th day of storage, compared with the fruit without packaging; the fruit handled in storage for 13 days presented pulp color between 3.8 and 4.2 ( $3=$ light yellow and $4=$ yellow-orange). Yamashita et al. studied the effect of packaging in polyvinyl chloride (PVC) on the shelf life of Tommy Atkins mangoes stored under refrigeration at $12{ }^{\circ} \mathrm{C}(80-90 \% \mathrm{RH})$; they found that the packed mangoes had a shelf life of 21 days against 6 days for non-packed, and that the mass loss rate was 3.5 times lower in the former [20]. The authors state that the combination of the packaging with storage at $12{ }^{\circ} \mathrm{C}$ increased product shelf life by reducing metabolic activity and the development of rot.
Jerônimo related that Tommy Atkins and Parvin fruits stored at $13{ }^{\circ} \mathrm{C}$ had shelf life 8 days longer than fruits stored at room temperature [21]. Fruits stored at $5{ }^{\circ} \mathrm{C}$ did not ripen and showed symptoms of cold damage.

For percentage of pulp yield, a significant decrease was observed from the 16th day of storage for fruits stored at room temperature (T1), and fruits washed and stored at room temperature (T3) (table V), due to the excessive ripening of the fruits, which were difficult to peel. Nevertheless, all treatments had yields above $60 \%$. For fruits stored at $12{ }^{\circ} \mathrm{C}(\mathrm{T} 2)$, fruits washed and stored at $12{ }^{\circ} \mathrm{C}$ (T4), fruits washed, packaged in PVC and stored at $12{ }^{\circ} \mathrm{C}(\mathrm{T} 6)$ and fruits of control (T7), there was no excessive ripening and no significant difference was observed within different periods of storage. Whatever the treatment, no significant difference was shown up to the 5 th day. On the 9 th day of storage, fruits washed, packed in PVC and stored at room temperature (T5) had the highest pulp yield percentage, differing significantly from fruits of treatments $\mathrm{T} 3$ and T4. After 13 days of storage, the highest yields were achieved in fruits of the treatments T7, T6, T4, T2 and T3. On the 16th 
Table V.

Averages of the unfolding interaction between storage periods and storage conditions for the parameter pulp yield (\%) of 'Espada' mangoes submitted to different treatments applied to fruits after harvest (South Brazil).

\begin{tabular}{|c|c|c|c|c|c|c|c|c|c|c|c|c|c|c|c|}
\hline \multirow{3}{*}{$\begin{array}{l}\text { Storage conditions } \\
\text { (treatments) } \\
\text { Room T }^{\circ}\end{array}$} & \multicolumn{15}{|c|}{ Storage periods (days) } \\
\hline & \multicolumn{3}{|c|}{5} & \multicolumn{3}{|c|}{9} & \multicolumn{3}{|c|}{13} & \multicolumn{3}{|c|}{16} & \multicolumn{3}{|c|}{21} \\
\hline & 75.06 & A & a & 74.44 & A & $a b$ & 70.67 & $A B$ & $\mathrm{bc}$ & 68.01 & $\mathrm{BC}$ & c & 63.49 & C & $b$ \\
\hline $12{ }^{\circ} \mathrm{C} / 80-90 \% \mathrm{RH}$ & 73.40 & $A$ & a & 74.08 & $A$ & $a b$ & 73.48 & $A$ & $a b c$ & 73.68 & $A$ & $a b$ & 72.77 & $A$ & a \\
\hline Washed + room $\mathrm{T}^{\circ}$ & 72.00 & $A$ & a & 70.91 & $\mathrm{AB}$ & $b$ & 69.31 & $A B$ & c & 66.56 & $\mathrm{BC}$ & c & 62.19 & $\mathrm{C}$ & $b$ \\
\hline Washed $+12^{\circ} \mathrm{C} / 80-90 \% \mathrm{RH}$ & 72.42 & $A$ & a & 71.96 & A & $b$ & 74.61 & $A$ & $a b$ & 75.53 & A & a & 73.23 & A & a \\
\hline $\begin{array}{l}\text { Washed + packed with PVC } \\
+ \text { room } T^{\circ}\end{array}$ & 74.58 & $A B$ & a & 77.35 & A & a & 72.87 & $A B$ & $a b c$ & 69.88 & B & $\mathrm{bc}$ & 63.58 & C & $b$ \\
\hline $\begin{array}{l}\text { Washed + packed with PVC } \\
+12^{\circ} \mathrm{C} / 80-90 \% \mathrm{RH}\end{array}$ & 74.72 & A & $\mathrm{a}$ & 75.63 & A & $a b$ & 76.08 & $A$ & a & 75.49 & $A$ & $\mathrm{a}$ & 71.44 & $A$ & a \\
\hline Fresh fruits & 76.96 & $A$ & a & 75.63 & A & $a b$ & 77.56 & $A$ & $a$ & 76.78 & $A$ & $a$ & 75.76 & A & a \\
\hline $\begin{array}{l}\text { Significant minimum difference } \\
\text { (storage periods) }\end{array}$ & \multicolumn{15}{|c|}{4.7946} \\
\hline $\begin{array}{l}\text { Significant minimum difference } \\
\text { (treatments) }\end{array}$ & \multicolumn{15}{|c|}{5.1852} \\
\hline
\end{tabular}

Table VI.

Averages of the unfolding interaction between storage periods and storage conditions for the parameter soluble solids ('Brix) of 'Espada' mangoes submitted to different treatments applied to fruits after harvest (South Brazil).

\begin{tabular}{|c|c|c|c|c|c|c|c|c|c|c|c|c|c|c|c|}
\hline \multirow{3}{*}{ 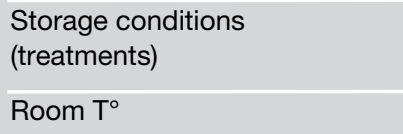 } & \multicolumn{15}{|c|}{ Storage periods (days) } \\
\hline & \multicolumn{3}{|c|}{5} & \multicolumn{3}{|c|}{9} & \multicolumn{3}{|c|}{13} & \multicolumn{3}{|c|}{16} & \multicolumn{3}{|c|}{21} \\
\hline & 7.44 & C & $\mathrm{a}$ & 8.58 & $A B$ & $a$ & 8.48 & $A B$ & $a b$ & 8.62 & $A$ & $a b$ & 7.58 & $\mathrm{BC}$ & $\mathrm{b}$ \\
\hline $12{ }^{\circ} \mathrm{C} / 80-90 \% \mathrm{RH}$ & 6.60 & B & $a b$ & 6.96 & $A B$ & $\mathrm{~b}$ & 6.98 & $A B$ & c & 7.20 & $A B$ & $\mathrm{~cd}$ & 7.92 & $A$ & $a b$ \\
\hline Washed + room $\mathrm{T}^{\circ}$ & 7.44 & $\mathrm{~B}$ & $\mathrm{a}$ & 8.40 & $A B$ & a & 8.88 & A & a & 9.06 & A & a & 8.92 & A & a \\
\hline Washed $+12^{\circ} \mathrm{C} / 80-90 \% \mathrm{RH}$ & 6.48 & $\mathrm{~B}$ & $a b$ & 6.70 & $A B$ & $b$ & 7.68 & $A$ & $\mathrm{bc}$ & 7.56 & $A$ & bcd & 7.70 & $A$ & $\mathrm{~b}$ \\
\hline $\begin{array}{l}\text { Washed + packed with PVC } \\
+ \text { room } \mathrm{T}^{\circ}\end{array}$ & 5.92 & $\mathrm{~B}$ & $\mathrm{~b}$ & 6.50 & $A B$ & $b$ & 7.26 & A & c & 7.40 & $A$ & $\mathrm{~cd}$ & 7.36 & $A$ & $b$ \\
\hline $\begin{array}{l}\text { Washed + packed with PVC } \\
+12{ }^{\circ} \mathrm{C} / 80-90 \% \mathrm{RH}\end{array}$ & 5.88 & B & $b$ & 7.00 & $A$ & $b$ & 7.12 & A & c & 7.82 & $A$ & $b c$ & 7.76 & $A$ & $b$ \\
\hline Fresh fruits & 6.44 & A & $a b$ & 7.04 & $A$ & $b$ & 6.68 & $A$ & c & 6.72 & A & $d$ & 6.92 & $A$ & $b$ \\
\hline $\begin{array}{l}\text { Significant minimum difference } \\
\text { (storage periods) }\end{array}$ & & & & & & & & 1.00 & & & & & & & \\
\hline $\begin{array}{l}\text { Significant minimum difference } \\
\text { (treatments) }\end{array}$ & & & & & & & & 1.08 & & & & & & & \\
\hline
\end{tabular}

and 21st days of storage, the lowest yields were observed in fruits of the treatments T1, T3 and T5, with the more ripe fruits. Pulp yield is a parameter used in cultivar selection for processing, juice nectars and other types of products, and cultivars with yields above $60 \%$ are prized [22].
A significant increase in soluble solids was noticed from the 9th day of storage for treatments T1 to T6 (table VI). For fruits stored at room temperature (T1), there was a significant decrease at 21 days of storage from $8.62{ }^{\circ}$ Brix to $7.58^{\circ}$ Brix, due to excessive fruit ripening, some of which had 


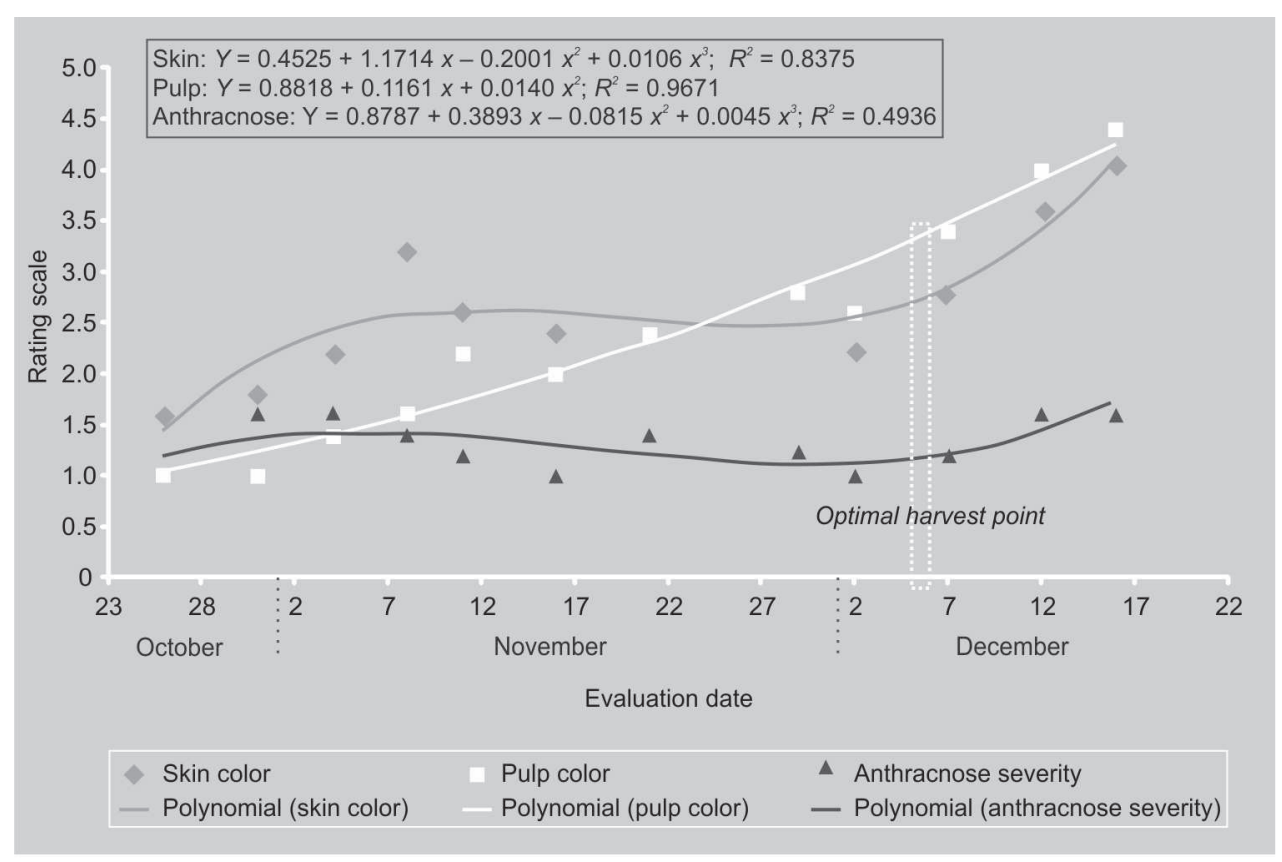

reached an improper state for consumption. For fruits of control (T7), there was no significant difference during the evaluation periods, due to the non-ripening of fruits. At the 5th day of storage, there was no difference among fruits from treatments $\mathrm{T} 1, \mathrm{~T} 2$, T3, T4 and T7. For the 9th, 16th and 13th days, fruits of treatments $\mathrm{T} 1$ and $\mathrm{T} 3$ showed the highest values of soluble solids, differing from the others. On the 21st day, the highest value of soluble solids was obtained for fruits of the treatment $\mathrm{T} 3\left(8.92{ }^{\circ} \mathrm{Brix}\right)$ and did not differ statistically from fruits of the treatment T2 $\left(7.92^{\circ} \mathrm{Brix}\right)$.

The largest increase in soluble solids occurred in fruits stored at room temperature, similar to the pattern seen for other parameters, and the largest delay in ripening was observed in fruit stored at $12{ }^{\circ} \mathrm{C}($ table VI). This pattern is found until the 16th day of storage. The evaluation at the 21st day showed no significant difference among fruits of treatments T2 and T3. Fruits packed in PVC showed the same behavior either stored at room temperature or at $12{ }^{\circ} \mathrm{C}$, and both conditions were effective in delaying the ripening of the fruits. Yamashita et al. reported an increase in the soluble solids content against time in Tommy Atkins mangoes stored at $12{ }^{\circ} \mathrm{C}$ for both mangoes packaged in PVC film and without packaging [20]. However, the control fruits (without packaging) had a greater increase $\left(12^{\circ}\right.$ Brix to $\left.17^{\circ} \mathrm{Brix}\right)$ than the packed fruits $\left(12^{\circ} \mathrm{Brix}\right.$ to $\left.14^{\circ} \mathrm{Brix}\right)$. It is likely that the packaging reduced the metabolic activity of the fruit, delaying ripening. In this experiment, there was usually a significant increase in soluble solids after the 5th day of storage and afterward the soluble solids content tended to remain quite stable toward the end of storage for fruits of all the treatments except T1 and T7. In fruits of $\mathrm{T} 1 \mathrm{a}$ significant decrease was measured on the 21st day, while there was no change in the samples evaluated in treatment $\mathrm{T} 7$.

Studies of the quadratic performance of pulp color and cubic performance of skin color and anthracnose severity of fruits evaluated in the field (T7) show that the skin color was stable from November 4 to December 7 [(134 to 167) days after the onset of flowering], with a rating scale between 2 and 3; it had an increase on For pulp color, an increase was found earlier, on December 7. For severity of anthracnose, the graphic scale remained between 1 and 1.5 for all evaluated dates (figure 1). December 12 (172 days after flowering).
Figure 1.

Variation in rates of skin color, flesh color and severity of anthracnose of 'Espada' mangoes submitted to different storage treatments, according to the dates of assessment (South Brazil).

- Skin color: 1 = green fruit, $2=$ more green than yellow, 3 = equal amounts of green and yellow, $4=$ more yellow than green, and $5=$ completely yellow fruits.

- Pulp color: 1 = light cream pulp, $2=$ cream pulp, $3=$ light yellow pulp, $4=$ yellow-orange pulp, and $5=$ orange intense pulp.

- Anthracnose severity: $1=$ no anthracnose spots on the fruits, $2=$ less than $5.0 \%$, $3=5.0 \%$ to $10.0 \%, 4=10.1 \%$ to $30.0 \%$, and $5=$ more than $30.1 \%$ of the fruit area affected, respectively. 


\section{Figure 2.}

Variation in rates of soluble solids ('Brix) of 'Espada' mangoes submitted to different storage treatments, according to the dates of assessment (South Brazil).

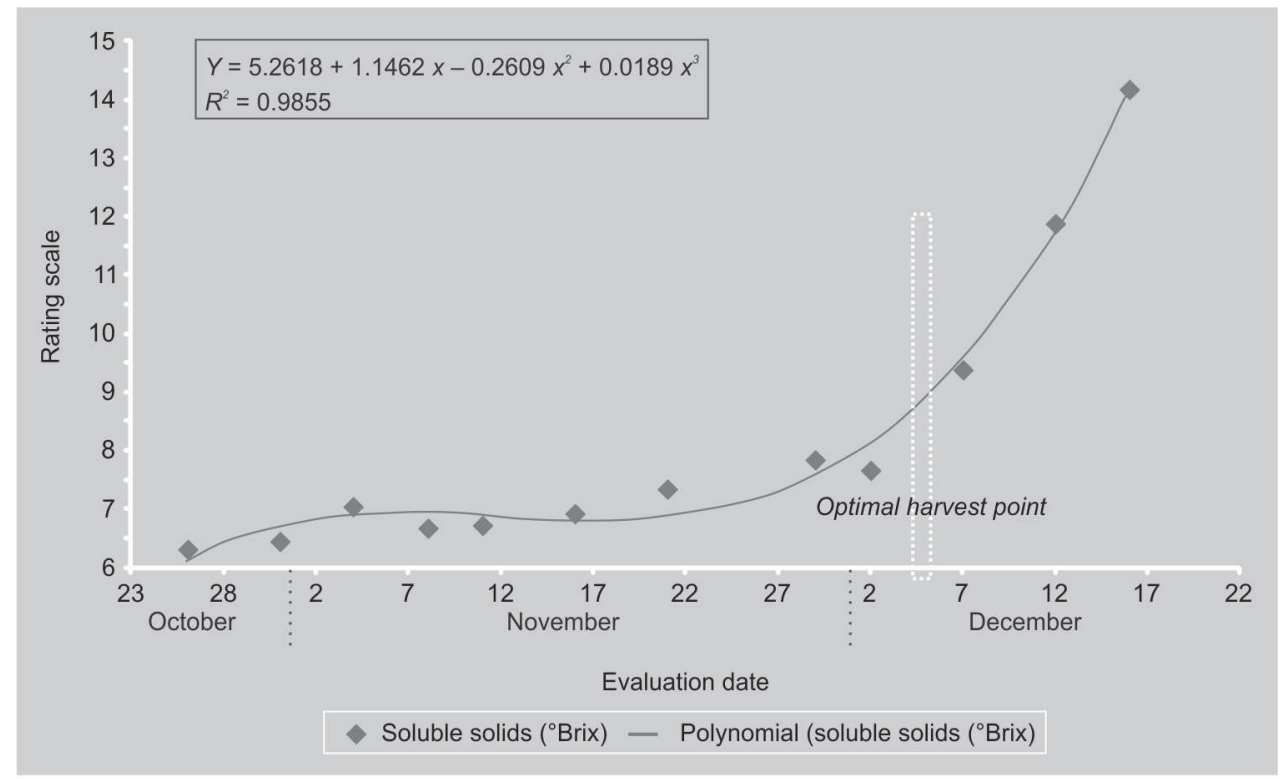

The following characteristics can be determined as the optimal harvesting point (figures 1, 2): harvest at 165 days after initiation of flowering, with skin color $=3$ (equal amounts of green and yellow), pulp color $=3$ (yellow pulp), and soluble solids of $8.5^{\circ}$ Brix.

The quality of mango for consumption and its postharvest conservation depend mainly on the stage of development of the fruit at harvest. Thus, fruits that did not complete their maximum physiological development in the field may be kept for a long period of time, but they will never reach the optimum quality for consumption [23]. According to Botton, harvesting at the inadequate physiological maturity stage is a major cause of loss and poor quality of Brazilian mangoes that reach Europe by sea [24]. The low level of anthracnose severity observed in all evaluations (figure 1) indicates the resistance of the Espada variety to the pathogen, since as it was an organic production system no fungicide was used.

The increase in total soluble solids for fruits in the field (T7) is illustrated by the rise in the curve (figure 2) from the evaluation on December 7 (at 167 days after the onset of flowering) from $7.7^{\circ}$ Brix to $9.4^{\circ} \mathrm{Brix}$, until the last evaluation date on December
16 (at 176 days), where levels reached $14.2{ }^{\circ}$ Brix, on average.

\section{Conclusions}

The storage of mango fruits at $12{ }^{\circ} \mathrm{C}$ and $80-$ $90 \%$ of relative humidity is more efficient in delaying fruit ripening, for the maintenance of skin and pulp color, and soluble solids contents, and for delaying the development of anthracnose symptoms. The use of PVC when storing fruits at room temperature makes it possible to keep skin and pulp color for 13 days, compared with 9 days with unpackaged fruits. The ideal time to harvest the Espada variety in the environmental conditions of the region of Pindorama, SP, Brazil, occurs at 165 days after the onset of flowering, with color of skin and pulp $=3$ (equal amounts of green and yellow and light yellow pulp) and soluble solids of $8.5^{\circ} \mathrm{Brix}$; The low severity of anthracnose found in the different evaluation periods indicates the probable resistance of the Espada variety to the pathogen.

\section{Acknowledgments}

The authors thank FAPESP for their financial support. 


\section{References}

[1] Yahia E.M., Modified and controlled atmospheres for tropical fruits, Hortic. Rev. 22 (1998) 123-183.

[2] Ben-Yehoshua S., Individual seal-packaging of fruit and vegetables in plastic film - a new postharvest technique, HortScience 20 (1985) 32-37.

[3] YamashitaF., Benassi M.T., Kieckbusch T.G., Shelf life extension of individually film-wrapped mangoes, Trop. Sci. 37 (1997) 249-255.

[4] Miller W.R., Spalding D.H., Hale P.W., Film wrapping mangos at advancing stages of post-harvest ripening, Trop. Sci. 26 (1986) 9-17.

[5] Melo Neto M.L., Christoffoleti P.J., Sigrist J.M.M., Alves, R.M.V., Utilização de embalagens plásticas e refrigeração na conservação da manga (Mangifera indica L.) cv. Palmer, Rev. Bras. Frutic. 21 (1999) 160-165.

[6] Jeronimo E.M., Kanesiro M.A.B., Efeito da associação de armazenamento sob refrigeração e atmosfera modificada na qualidade de mangas Palmer, Rev. Bras. Frutic. 22 (2000) 237-243.

[7] Medlicott A.P., Reynolds S.B., Thompson A.K., Effects of temperature on the ripening of mango fruit (Mangifera indica L.) var. Tommy Atkins, J. Sci. Food Agric. 37 (1986) 469-474.

[8] Esguerra E.B., Lizada M.C.C., The postharvest behavior and quality of 'Carabao' mango subjected to vapor heat treatment, ASEAN Food J. 16 (1980) 704-712.

[9] Peacock B.C., Murray C., Kosiyachinda S., Kosittrakul M., Tansiriyakul S., Influence of harvest maturity of mangoes on storage potential and ripe fruit quality, ASEAN Food J. 2 (1986) 9-103.

[10] Brecht J.K., Yahia E.M., Postharvest physiology, in: Litz R.E. (Ed.), The mango: botany, production and uses, 2nd ed., CABI Publ., U.K., 2009, pp. 484-528.

[11] Hiluey L.J., Gomes J.P., Almeida F.A.C., Silva M.S.,AlexandreH.V., Avaliação do rendimento do fruto, cor da casca e polpa de manga tipo Espada sob atmosfera modificada, Rev. Bras. Prod. Agroind. 7 (2005) 151-157.

[12] Sales Júnior R., Costa F.M., Marinho R.E.M., Nunes G.H.S., Amaro Filho J., Miranda V.S., Utilização de azoxistrobina no controle da antracnose da mangueira, Fitopatol. Bras. 29 (2004) 193-196.
[13] Cunha G.A.P., Pinto A.C.Q., Ferreira F.R., Origem, dispersão, taxonomia e botânica, in: Genú P.J.C., Pinto A.C.Q. (Eds.), A cultura da mangueira, Embrapa Inf. Tecnol., Brasília, DF, Brasil, 2002.

[14] Filgueiras H.A.C. (Org.), Manga. Pós-colheita, Embrapa Comun. Transf. Tecnol., Brasília, Brasil, 2000.

[15] Prusky D., Kobiler I., Miyara I., Alkan N., Fruit diseases, in: Litz R.E. (Ed.), The mango: botany, production and uses, 2nd ed., CABI Publ., U.K., 2009, pp. 210-230.

[16] Pesis E., Aharoni D., Aharon Z., Ben-Arie R., Aharoni N., Fuchs Y., Modified atmosphere and modified humidity packaging alleviates chilling injury symptoms in mango fruit, Postharvest Biol. Technol. 19 (2000) 93-101.

[17] González-Aguilar G., Gardea A., MartinezTellez M.A., Baez R., Felix L., Low oxygen treatment before storage in normal or modified atmosphere packaging of mangoes to extend shelf life, J. Food Sci. Technol. 34 (1997) 399-404.

[18] Alves M.V., Sigrist J.M.M., Padula M., Atmosfera modificada em mangas 'Tommy Atkins', Rev. Bras. Frutic. 20 (1998) 220-228.

[19] Medlicott A., Sigrist J., Sy O., Ripening of mango following low-temperature storage, J. Am. Soc. Hortic. Sci. 115 (1990) 430-434.

[20] Yamashita F., Tonzar A.C., Fernandes J.G., Moriya S., Benassi M. de T., Embalagem individual de mangas cv. Tommy Atkins em filme plástico: efeito sobre a vida de prateleira, Rev. Bras. Frutic. 23 (2001) 288-292.

[21] Jeronimo E.M., Efeito do uso de embalagens associadas a armazenamento sob refrigeração, na conservação pós-colheita de mangas 'Tommy Atkins' e 'Palmer', Univ. Fed. Paulista, Diss., Jaboticabal, Brasil, 2000, 121 p.

[22] Folegatti M.J. da, Matsuura F.C.A.U., Torrezan R., Botrel N., Souza Filho M. de S.M., Azeredo H.M.C., Brito E.S. de, Souza Neto M.A., Processamento e produtos, in: Genú P.J.C., Pinto A.C. de Q. (Eds.), A cultura da mangueira, EmbrapaInf. Tecnol., Brasília, DF, Brasil,2002.

[23] Guarinoni A., Efecto del estado de madurez de los frutos a la cosecha sobre su conservación, in: Proc. II Congr. Iberoam. Tecnología Postcosecha y Agroexportaciones, Bogotá, Colombia, 2000, pp. 29-38.

[24] Botton C.G. de, Avaliação da qualidade de mangas transportadas por via marítima chegando na Europa pelo porto de Roterdã, Holanda, Rev. Bras. Frutic.14 (1992) 121125. 


\section{Almacenamiento de mangos 'Espada' en una atmósfera modificada y refrigerada: efectos en la conservación de las frutas.}

Resumen - Introducción. Brasil es un importante productor de mangos, pero el volumen de las exportaciones aún es débil debido a la corta duración de conservación de estas frutas. El objetivo de nuestro trabajo fue evaluar, en función de distintos periodos de conservación, el efecto de la modificación de la atmósfera de almacenamiento mediante la utilización de una película de plástico, así como el efecto de la temperatura de almacenamiento, en las características de los mangos Espada de cultivo biológico. Material y métodos. Se aplicaron siete tratamientos a las frutas tras su recogida: frutas conservadas a temperatura ambiente; a $12{ }^{\circ} \mathrm{C} / 80-90 \%$ de humedad relativa (HR); lavadas y almacenadas a temperatura ambiente; lavadas y almacenadas a $12{ }^{\circ} \mathrm{C} / 80-90 \%$ HR; lavadas, embaladas con PVC y conservadas a temperatura ambiente; lavadas, embaladas con PVC y conservadas a $12{ }^{\circ} \mathrm{C} / 80-90 \% \mathrm{HR}$; frutas recogidas en la misma fecha que las evaluaciones realizadas tras $(5,9,13,16$ y 21) días de almacenamiento en los otros seis tratamientos. Resultados y discusión. El almacenamiento a $12{ }^{\circ} \mathrm{C} / 80-90 \%$ HR resultó más eficaz para retrasar la maduración de las frutas, con una evolución menor de los colores de la piel y de la pulpa y contenido en sólidos solubles; asimismo, dicho tratamiento retrasó el desarrollo de antracnosis. Las frutas conservadas con PVC y colocadas a temperatura ambiente conservaron el color de la piel y la pulpa durante 13 días, mientras que las frutas no embaladas tuvieron 9 días de conservación. El mejor momento para la recogida de la variedad Espada sería 165 días tras el comienzo de la floración, con un índice de color 3 de la piel (cantidades iguales de verde y amarillo) y de la pulpa (pulpa amarilla), y un contenido en sólidos solubles de $8,5^{\circ}$ Brix. La poca gravedad de la antracnosis encontrada en las diferentes fechas de evaluación indicaría una posible tolerancia de la variedad Espada al agente patógeno.

Brasil / Mangifera indica / frutas / maduración en postcosecha / almacenamiento atmósfera controlada / aptitud para la conservación 